\title{
Marilynne Robinson's Housekeeping: Sylvie's Fundamental Mentorship through New Western Historicism and Ecofeminist Criticism
}

\section{Amanda Zastrow}

\begin{abstract}
In the novel Housekeeping, Marilynne Robinson discusses main character, Sylvie's, relationship with nature in a way that revises what many New Western historians view as the Old West's destructive ideology toward nature. Sylvie lives in opposition to what is seen as the aggressive mannerisms of Old Western males, individuals who have attempted to conquer both women and nature through their disregard for the female histories of the Old West as well as through their degradation of the faultless Western land. An effort that brings together both of these ideas, a concept that connects the maltreatment of women as well as of nature throughout history, ecofeminist philosophies are, in turn, relevant to a discussion of Robinson's Sylvie and her New Western principles. Both viewpoints express a historical overlap of women and nature; therefore, Sylvie's actions, which contradict the conquering mentalities of the Old West, also align with fundamental ecofeminist principles. Her actions throughout the novel possess an understanding and admiration of nature's character as well as a voice that disagrees with the mistreatment that it receives.
\end{abstract}

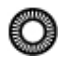

Published in 1980, Marilynne Robinson's first novel, Housekeeping, tells the story of vagrant traveller, Sylvie, who returns to her childhood home in Fingerbone, Idaho, to take care of her orphaned nieces, Ruth and Lucille. As the novel is set in the mid-twentieth century, Robinson's use of the title Housekeeping draws attention to what most of the conventional townspeople find lacking in the allfemale household. Sylvie is not the traditional mother and homemaker that this Western town expects her to be. Upon her arrival as the girls' guardian, Sylvie's presence immediately causes her childhood home to transform from the domestic space that it once was - while her mother was alive - into a new space that defies the long-established principle that a female's role is to remain within the home and to "keep house."

In the novel, Robinson portrays Sylvie's relationship with the outside world in a way that revises what many New Western historians view as the Old West's 
destructive ideology toward nature. I argue that Sylvie is the New Western foil to what many of these historians see as the aggressive mannerisms of Old Western males, individuals who attempt to not only conquer the feminine land but also attempt to control females as well as the earth they stand on. My argument that Sylvie is a noble character in defense of New Western principles reflects Robinson's attempt, as a New Western writer, to shed light on the aspects of the Old West's traditional neglect of female characters and the abuse of feminized land in Western literature and history. Expanding on New Western historians' efforts of revision, I argue that, due to Robinson's great attention to the majestic Idaho landscape and to Sylvie's respect and reverence for nature, claims from New Western historians like Donald Worster's charge against the Old West for the "ruthless assault on nature [that] has left behind it much death, depletion, and ruin" can be tied to what ecofeminists assert as a rejection of "the notion that Man's freedom and happiness depend on an ongoing process of emancipation from nature, on independence from, and dominance over natural processes" (Worster 18; Mies and Shiva 6). Sylvie's actions and conversations that exhibit New Western traits occasionally overlap with ecofeminist theory. The novel, through its depiction of New Western history, point to ecofeminist ideas which call for the recognition of the value of women and land in understanding American history extensively.

It was during the early period of ecofeminism's emergence that Robinson was penning Housekeeping,which connected to nature in a way that aligns with many ecofeminist principles. The novel also predates and anticipates Robinson's own texts, Mother Country and "Surrendering Wildness," which centre on environmental concepts and beliefs. Sylvie, a character whose existence largely finds and encompasses itself within the beauty and revelation that the Idaho landscape brings her, represents the very type of soul that Robinson and ecofeminists feel is needed in our world. In her 1998 essay "Surrendering 
Wilderness", Robinson addresses the "defects" in society, which is similar to those discussed by Donald Worster. However, while Worster blames the West for the "violence [...] secured against the continuing claims of minorities, women, and the forces of nature," Robinson acknowledges that this issue of "our onerous dominion" has long been a controversial issue since "the oldest anecdotes from which we know ourselves as human," even before the American West was a concept of historical or pop culture (Worster 11-12; M. Robinson 60). Of humans, she says that "it [is] clear that our defects are sufficient to bring the whole world down" and that our attempts to master control over nature and the environment have "caught [us] up in something much larger" than we had expected. Robinson states that the "variety and seriousness" of our environmental issues seem to "persuad[e] [us] that we may be approaching the end of the day" (60). Similarly, critic George B. Handley sees the 1989 text Mother Country as one that voices Robinson's powerful views on environmentalism. In Handley's interview with Robinson, he states the text "provides a trenchant critique" of England's issue with nuclear waste and "challenges assumptions about what it means to be moral politically, environmentally, and socially" (59). Robinson's views on moral environmentalism are also discussed in the interview:

I'm profoundly critical of the environmental movement. Not because I have any problems with the idea that the environment needs to be rescued, but in the sense that I think that they [environmental activists] have been stunningly ineffective. [...] I write about landscape and the human investment in landscape and vice versa, I mean the investment of the soul, because I want to make people love where they are. I think that the best defense, the best sort of on-the-ground defense for any landscape is to have people love it, and any landscape deserves that. (Handley 63)

Clearly, Robinson's moral environmentalism is the influence behind Sylvie's behaviours regarding nature and the outside world as many situations in her 
novel are examples of this "best defense", in which Sylvie celebrates the wonder of the outside world and enjoys the internal responsiveness nature evoked within her. Just as Handley writes that Robinson confronts a "pattern of denial and contradiction in her native home in the West, where the love of remote wild lands often goes hand-in-glove with wanton abuse," Sylvie represents an ecofeminist whose love for this land fights against the "wanton abuse" committed against the female population and nature by the patriarchy of the West (63).

While both New Western historians and ecofeminists focus much of their discussion on the inadequate and harmful treatment of nature throughout Western American history, specific similarities can be found when considering some of ecofeminism's most obvious points. New Western historian Richard White states that the reality of the American West is emphatically a "product of [white men's] conquest," a conquest that was the result of the "brutal mistreatment of women, minorities, and the environment - crimes for which they refuse to accept responsibility" (qtd. in F. Robinson 71-2). While writer Greg Lyons echoes White through his contention that the majority of current writing on the West "records a tragic destruction" of natural environments, he later expresses that New Western writing on nature at times resembles a balancing act as it attempts to level "John Muir's unbridled enthusiasm with Rachel Carson's warnings of environmental apocalypse," an effort that Lyons observes often "combines scientific research with poetic interpretations and personal reflections" (424). Ecofeminists share the New Western historians' concern that both nature and women are "denigrated and manipulated," and it is what ecofeminists Irene Diamond and Gloria Feman Orenstein term "masculine consciousness" (ix). Further, aspects of ecofeminist theory can also be seen as a balance between a fervour for nature and the impending dread that current environmental actualities elicit (ix). Ecofeminists ground their discussion of nature between what, they argue, is a required stunned reverence for nature's 
mystique and their more enraged convictions that assert blame on the patriarchy's "urge to negate one's dependence on the natural world" (Kheel 137). This is a phenomenon they find greatly linked to concepts of environmental decay such as the "environmental apocalypse" described in Rachel Carson's Silent Spring (137). Thus, Lyons' description of New Western nature writing has much in common with ecofeminist writing. Both discuss an individual's awestruck personal impressions and observations of nature, as well as address accurate historical information in relation to real environmental disasters. With regard to nature, New Western historians and ecofeminists express many of the same ideas and beliefs.

Literary critics who have discussed Robinson's novel using an ecofeminist lens include writer Jadwiga Maszewska, who argues that women are connected to nature. She states that through the patriarchal "control of language, woman becomes man's other", and since nature is man's other, "both woman and nature are placed in the mute position of objects to be defined in the language of their respective subjects but themselves voiceless" (67). Using theories from Maureen Devine, author of 1992's Women and Nature, Maszewska contends that in Housekeeping, "Robinson makes an effort to find a language for nature" in order to find one for women (68).

Other critics have looked at Robinson's use of nature and its connection to the Transcendentalism movement of the nineteenth century. For example, literary critic Judie Newman explains Housekeeping as a novel that portrays "women engag[ing] with the myth" of the "solitary sojourner in nature," the plotline that Emerson and Thoreau employed within various Transcendental pieces of literature $(304,303)$. Critic Hannes Bergthaller also writes of how Robinson's novel "engage[s] in a dialogue with this [Transcendental] tradition" (83). While many have discussed Robinson's use of nature and the outside world, critics have not focused on the novel's belief in a need for change, a motif that 
can be found by considering the ecofeminist tones of the novel, as well as the New West's argument for the revisioning of female and nature roles. In fact, relatively few critics have centered their arguments about Housekeeping through an analysis of the American West, and those like Tony R. Magagna, who have argued for the West in terms of place theory. Alternatively, Sheila Ruzycki O'Brien and Corina Crisu have focused on aspects of Robinson's writing in comparison to other writers and themes within the Western tradition.

Unlike other Robinson critics, I will focus my arguments on the way that Robinson's novel represents the modifications necessary for our environment to flourish today and how the relationship between ecofeminism and the New Western perspective shows Robinson's sentiments towards change. Robinson uses the character Sylvie to address these concepts through her mentorship with her niece, Ruth. The novel closes with a vagrant Sylvie and Ruth whose forced transience seems to represent the world's lack of place for non-traditional women. Therefore, despite efforts of resistance, Robinson's characters lack a place of belonging from which to ask readers to acknowledge what measures needed for a future of gender equality.

Throughout the novel, Robinson constantly points to Sylvie's relationships with nature and Ruth's work to describe possible currents that could lead to an altered future, and this relates to the ecofeminist reverence for and defense of nature. The consistent positioning of Sylvie as a metaphor for unconventionality can also be seen through Sylvie's understanding and awe of nature within the novel. As ecofeminist Linda Vance states, a passion for eradicating the diminishment of females and of nature comes from feelings of "inspiration and alternative ways of knowing" that can only be found within the outdoors (130). For Vance, the time in the forests of Vermont left her feeling "blessed by the presence" of nature (129). Likewise, Robinson's numerous descriptions of the majestic Idaho landscape paired with Sylvie's various interactions with nature 
express Sylvie's comparable comfort and excitement that she encounters during her various wanderings in the outdoors of Fingerbone. For example, early in the novel, the nature of Sylvie's feelings for the outside world becomes clear to Ruth as Robinson foreshadows Sylvie's future mentorship of her niece. Ruth, who, along with Lucille, has been skipping school and spending time at Lake Fingerbone, recalls that the ambiance of the beach (along with the dismal reality of their illicit truancies) has produced "combined effects of cold, tedium, guilt, loneliness, and dread" within their hearts and that their time at the lake has made them feel "small in the landscape, and out of place" (79). Upon seeing Sylvie on the shore, however, Ruth can tell that, for Sylvie, Fingerbone's natural elements have quite the opposite effect. While the girls are sitting so that "she should have seen us," Sylvie is oblivious to her nieces' presence (80). Rather, Ruth observes that Sylvie "stood looking at the lake for a long time, her hands deep in the pockets of her big, drab coat and her head to one side, and lifted, as if she hardly felt the cold at all" (80). Immune to all of the secular distractions around her, Sylvie behaves as if she and nature are old friends, comfortable in each other's traits and qualities as well as in each other's silences. Ruth notices that her aunt gives her attention to the lake as if through years of correspondence, she has grown not only fond of the world's natural elements, in that she enjoys watching it, but she also has an immense respect for it as she does not try to impress her own being onto the natural affect of the space surrounding her. The temperature, naturally dictated by the lake's breeze, also does not bother Sylvie as it does Ruth and Lucille. She is perfectly at ease, her head cocked in contentment as she revels at simply being in nature. Ruth does not quite understand Sylvie's angle in addressing the lake's natural essence, but she can see that the outdoors is a place where Sylvie feels peace and understanding. Here, Sylvie's behaviours and attitudes align with Linda Vance's response to nature: 
Sylvie's calm demeanour and quiet approach to the lake express that she likely feels quietly elated in the presence of such beauty and serenity.

While Sylvie's bringing of the outside world into the home can be seen as resistance to the rigid Old Western gender binary in the town of Fingerbone, Ruth's description of this tactic can also be analyzed in terms of Sylvie's relationship with nature and the peace and pleasure that the outdoors brings her. Ruth knows that Sylvie clearly enjoys her time in nature, and as time passes, Ruth begins to understand that Sylvie's alliance with the natural world can be just as powerful indoors as well. Plagued by an annual flood, Fingerbone families are forced to manage on the second floor for days as their houses become saturated with water. An example of the Old Western tendencies of the town is when Ruth's sister, Lucille, attempts to control and contain the unruly water. Lucille stomps her feet as "water sloshed against the walls" like it was being "carried in a bucket" (Robinson 64). Sylvie and Ruth, however, move gracefully through the water, "six grand waltz steps," as their joyful dancing acknowledges that this water will not be held in a vessel, and that it will not allow its existence to be hindered by a bucket or by a house or by any other humanly-created enclosure (64). At this point in the novel, water permeates into every crevice of their home and Sylvie welcomes its presence as she prances throughout their sopping home with Ruth, celebrating the very existence of such a strong and powerful force. She understands water as naturally occurring and embraces its intrinsic qualities.

While Sylvie is clearly a proponent for nature, Robinson's desire to inspire historical change through her characters' interactions with nature becomes more obvious during an especially memorable section of the novel that highlights both Sylvie's delight in nature as well as Ruth's emerging appreciation and understanding. Toward the end of the novel, the two women wake early in the morning for an all-day experience across the lake and onto an uninhabited island. Ruth begins this story by remembering Sylvie's recognition and understanding of 
the outside world. For example, as the two set out in the early morning mist, Sylvie "borrows" a boat to take them to an island, and while in process of pushing the boat into deeper water, Sylvie abruptly ends her conversation with Ruth. As Robinson writes, "Sylvie looked at the sky and said no more" (149). Because of Sylvie's silence, a moment perhaps brought on by the stunning morning sky and Sylvie's attention to its natural beauty, Ruth begins to look around her and experiences feelings of wonderment and beauty in what she can see:

I peered over the side now and then, into the murky transparencies of the upper waters, which were clouded and crude as agate. The fragmented image of jonquil sky spilled from top to top of the rounding waves as the shine spills on silk, and gulls sailed up into the very height of the sky, still stark white when they could just be seen. To the east the mountains were eclipsed. To the west they stood in balmy light. Dawn and its excesses always reminded me of heaven. (149)

Here, Sylvie's values and appreciations of nature are expressed not only through her silence, what seems to be her repeated, instinctual reaction to nature, but also through Ruth's coming to terms with this experience. Ruth, who at several points in the novel is described as like Sylvie, represents Sylvie's love for the natural world as she consistently has learned from Sylvie's knowledge of nature. Ruth's blossoming love and reverence for nature is a byproduct of Sylvie's intense devotion to her environment. Ruth's burgeoning relationship with nature is illustrated here through cloudy and partial images such as 'fragmented,' 'eclipsed,' and 'murky,' terms that express that Ruth is still learning. She is still working to define a more polished perspective of nature, and her viewpoint is not as open or as willing as Sylvie's ecofeminist outlook is. Hence, Robinson's use of descriptions depict incompleteness and lack of clarity. However, Ruth's acknowledgment of what surrounds her aunt's silent respect shows that Sylvie's mentorship of Ruth is progressing: the feeling of awe that Sylvie finds in nature 
is being shared and stressed. Sylvie's connectedness and respect for nature effectively express and share with Ruth the reason behind an ecofeminist's fight against the patriarchal ruin of the outside world.

Sylvie's reverent attitudes toward nature are made clear throughout the novel as her behaviours assign her the role of advocate against patriarchal society, and Robinson's discourse on the concept of rebirth works to suggest an achievable step toward the goal of gender equality. A topic that directly connects to ecofeminist content, the maternal relationship between Sylvie and Ruth allows for Ruth to adopt Sylvie's already existing nonconformist, anti-patriarchal behaviours and to be reborn as an additional New Western, ecofeminist hero. While there are many instances of Ruth learning from Sylvie in such a way that she becomes like her aunt, Ruth's understanding of Old Western and ecofeminist principles really begins during the aforementioned section, when she and Sylvie travel by boat to the little island at the centre of Lake Fingerbone. On this occasion, Ruth's developing relationship with nature allows for her to imagine a new type of world in which Sylvie would bring them into a place where everyone belongs (Robinson 149-50). During the trip, Ruth's transformation begins as she realizes the necessity of this rebirth, and as she recognizes that she has felt out of place all of her life, reduced to an unborn infant, mindlessly trailing after her grandfather "in some ethereal current" (149). Because of the Old Western patriarchy of Fingerbone, she has been left to blindly follow this male authority figure and to live in a liminal space that does not allow her to maintain a real identity (149). Sylvie's presence, her respect for the natural world, and her representation as a New Western hero offers to Ruth an occasion of rebirth, or perhaps her first real birth, as she discusses later. As she begins to see the world in such a way that mirrors Sylvie's behavioural reverence and defense of nature, Ruth is able to imagine her life separated from the domineering patriarchal oppression she has always known. 
Robinson offers many examples of maternal language - fittingly, due to Sylvie's role as a mother figure - in Ruth and Sylvie's trip across the lake as Ruth's rebirth occurs. For instance, Sylvie is described as being motherly to Ruth early in the trip as she hands Ruth "an egg out of the frying pan" for breakfast (144). An egg, as critic Sonia Gernes notes, represents "the archetypal feminine symbol for fertility and gestation," and through her gifting of this egg, Sylvie prepares Ruth for the ceremony of identification rebirth that will soon occur (157). Sylvie is imaginatively fertile; she is ready to offer Ruth her knowledge and to spur Ruth's introspection and development. Specific instances of word choice during this extended scene mirror the birthing process, as well as suggest that Ruth's experience with Sylvie is the cause of rebirth for young woman. For example, while walking to their boat, Ruth notes that it seems natural to mimic Sylvie's walk as her aunt marches in front of her, leading the way. Ruth says:

I put my hands in my pockets, and tilted my head, and strode, as she did, and it was as if I were her shadow, and moved only because she moved and not because I willed this pace, this pocketing of the hands, this tilt of the head. Following her required neither will nor effort. I did it in my sleep. (144-5)

Here, Ruth's actions become like Sylvie's as she moves in tandem with her aunt's walk and stance. Like an infant in the womb, all of the effort of this imitation resides with mother Sylvie; Ruth is able to become like her by simply being with her. In this scene, Robinson repeats her description of Sylvie's signature head tilt as well. Ruth mentions that on this walk, she tilts her head just as Sylvie does, which hearkens back to Sylvie's repeated stance when in the presence of remarkable nature. Thus, Sylvie's maternal mentoring shows her niece how to react to the world around her as she would, and to accept it as it is, without domination and subjugation. Similarly, while preparing to board the boat, Ruth watches Sylvie and thinks, "We are the same. She could as well be my mother. I crouched and slept in her very shape like an unborn child" (145). Once again 
likening her situation to that of an unborn baby, Robinson suggests to readers that Ruth's latching on to Sylvie's eccentricities parallels a baby's form being shaped by a mother's frame, as Ruth willingly becomes like Sylvie, both physically and mentally.

Moving beyond the womb, birthing language is also used to describe Ruth's immersion into the world as she becomes a new being, one whose respect for nature and thus disdain for the Old West becomes more solidified. While boarding the boat, Sylvie says to Ruth that she has to "sit in that seat" in order to steer the boat; thus, Ruth "crawled under her body and out between her legs," enacting the leaving of the birth canal and the entrance of Ruth into the world as a changed being (146). As their trip progresses, this rebirth is evident as Ruth's appreciation for nature leads her to remark on this simply stunning island, or as she terms it, "Carthage sown with salt" (152). She expresses that, while before she may not have understood Sylvie's conception of nature and what's been argued as its connection to woman's rights and freedoms, she has now become enlightened, as she imagines that this island could be the utopia for which she and Sylvie are looking. Separated by water from the town of Fingerbone, Robinson is deliberate in her representation of Ruth's imagined Carthage as an island. This refuge is not only physically removed from and unattached to the patriarchal society that is dominant, but also this place of vision is surrounded by water, as if Robinson is offering the two women a natural defense from all angles as Ruth works through her thoughts regarding this imagined perfect place. In her new mind, Ruth sees the island as a garden, ripe with flowering in which "light would force each salt calyx to open in prisms, and to fruit heavily with bright globes of water" (152). Through a description that recognizes not only this scene of natural beauty but also her own awakening to its brilliance, Ruth conveys that if earlier she had not completely understood Sylvie's assurances, her mind has now been illuminated. The "light" that is Sylvie has allowed for a literal "flowering" within 
this garden, resulting in born "fruit," or realized knowledge, and thus, a flowering in Ruth's conception of what nature is and of the wonder that it can create. Through this moment of clarity, Ruth says that she sees "a foreshadowing - the world will be made whole": thus, the patriarchy will no longer be able to divide people from nature and men from women based on supposed worth (152). Ruth's vision of this utopic place - a New Western, ecofeminist future - leads to an optimistic belief that something could really happen, as she relays, "Any child who saw once how the gleaming water spilled to the tips of branches, and rounded and dropped and pocked the softening shadows of frost at the foot of each tree, would come to see it again" (153). Thus, this "gleaming water" is catching: it is beautiful to look at, and it "spills," it spreads to "each tree," metaphorically to each woman. And it is something that children will admire and will want to see more of. Once the beauty of this equality is known, who will want it to dry up again? Ruth suggests that children, a symbol of the future, will see the necessity of sharing this wisdom and of eradicating the oppression of the past; thus, once all are aware of this perfect world, no one will want to return to the patriarchal world of the past. A vision steeped in the recognition of nature's beauty as well as the hope for a future of gender equality, Ruth's soul has obviously been changed due to Sylvie's influence. Ruth now sees the potential for the type of future that ecofeminists and New Western historians alike envision, and Ruth as well wishes for it as a reality.

Earlier in the novel Ruth and Lucille had made a snowwoman that had literally lost its head under the glaring eye of Fingerbone's Old Western society; in this section, however, Ruth creates a second snowwoman, representing a renewed hope that offers readers a glimpse at a future in which New Western beliefs are achievable. As she is on the island, and Sylvie has left her to realize her own understanding of the wonders of nature and the symbolic occurrence of female expression, Ruth says, "If there had been snow I would have made a 
statue, a woman to a stand along the path, among the trees" (153). Perhaps metaphorically in reference to women, Ruth wants her snowwoman to be among nature and among those historically oppressed as "others." To make this idea clear, Ruth suggests that Lot's wife - a woman biblically shamed for having emotions, for acting on the "loss and mourning" that she felt following the destruction of her city and thus her life - is there among the trees and the snow. Making the independent decision to have "looked back," Lot's wife, a woman not even allotted her own name, is called by Ruth to be among the first to be revered with "rare flowers" shining "in her hair, and on her breast, and in her hands" (153). As if to redeem all women of the disgrace that's been forced upon them while attempting to assert their own agency, Ruth wishes for Lot's wife to be the first example of an altered understanding of history. Once again, "[t]he children would have come close, to look" at these women and to "love and marvel" at them, and in Ruth's mind, this time, the snowwoman would not fall. She would not be smashed by the patriarchy and its disbelief in a woman's ability to construct creatively. Rather, the children will come and will continue to return "eagerly": they will want to understand this previously misunderstood concept of female independence and power. They will be glad when this snowwoman "would be more than a mother to them, she so calm, so still, and they such wild and orphan things" (153). Here, the role of women is redefined as something more than motherhood. Ruth suggests that women, calm and assured, will be able to impact the children of the world, who are wild and without teachers. Rather than being defined by their motherhood, Robinson uses the pliancy of water to impart that a woman's role can also be fluid. This snowwoman can be a mother, but she can be more than that; her role is not stagnant as the Old West would wish to suggest. Through this passage, Sylvie's role as one offering rebirth also extends to the infinite children of the world. Because of Sylvie's role as a New Western hero, Ruth sees, in her own prescient mind, a place in which women will able to 
guide the world's young hearts and minds to understanding and promotion of female freedom of expression. Having created this work of art, Ruth, in her revised mindset, can stand and can play an important role in the future, and envision a world unlike that of present-day Fingerbone.

As it becomes evening, Ruth again expresses thoughts that reflect Sylvie's beliefs of nature as well as her own adoption of Sylvie's viewpoints. Sylvie and Ruth once again board the boat, and as they head out on the lake, Ruth begins to imagine that their boat might capsize. Rather than this being a disadvantageous event, however, Ruth contemplates that,

It was the order of the world that the shell should fall away and that I, the nub, the sleeping germ, should swell and expand. Say that the water lapped over the gunwales, and I swelled and swelled until I burst Sylvie's coat. Say that the water and I bore the rowboat down to the bottom, and I, miraculously, monstrously, drank water into all my pores until the last black cranny of my brain was a trickle, a spillet. (162)

Ecofeminist Marti Kheel describes such an event as "our deep, holistic awareness of the interconnectedness of all of life" (136-7). As Ruth imagines herself becoming one with the water, the boat or the shell falling away as she soaks the water into her being, she acknowledges a fundamental concept of ecofeminism that all components of life on Earth are intertwined and a part of one another. Ruth describes herself and the water as a joint unit that results in her appreciating nature as an entity no different than herself. As Kheel states, ecofeminism is a deep philosophy in that it "call[s] for an inward transformation in order to attain an outward change," that human beings must undergo self-realization and begin to "cease to understand or see ourselves as isolated and narrow competing egos" (128). Due to Sylvie's deep understanding and communion with nature, Ruth, who is becoming more and more like her, understands that this is "the order of the world"; she has been transformed to react to and see the outside world in the 
same manner as Sylvie. George Handley affirms this idea as he states, "[t]he hope that Robinson's work embodies is the hope of transcendence, of communicability, of some claim, however tenuous or temporarily suspended, that we are conjoined with the universe" (88). Thus, because of Sylvie's interactions with nature, Ruth has gained wisdom from her aunt and has begun to see herself as part of something larger, something that does not differentiate but rather allows for community between humans and all aspects of nature.

Where before Ruth looked out over the lake and remembered her lack of identity, Ruth now sees herself and the natural world as a duo that will result in her continued rebirth. As critic Heather Bohannan writes, "[c]entral to Ruth's transformation is a symbolic rebirth that takes place during the night spent on the lake with Sylvie"; thus, Ruth has been reborn (xx). She will take all of this water and all of these deep connections between women and nature with her, as a part of her, into the future. These thoughts of a feminist baptism lead Ruth to consider, "Then presumably, would come parturition in some form, though my first birth had hardly deserved that name" (162). Thus, while Ruth does not consider her first birth to a "real" birth, one in which she had been able to have an identity of her own, this rebirth that Sylvie has assisted has overcome the patriarchal dominance that had attempted to control her life. Ruth consumes nature in an effort to have a new identity, to be reborn as a new person. 


\section{Works Cited}

Bergthaller, Hannes. "Like a Ship to Be Tossed: Emersonian Environmentalism and Marilynne Robinson's Housekeeping." Culture, Creativity and Environment: New Environmentalist Criticism, edited by Fiona Becket and Terry Gifford, Rodopi, 2007, pp. 75-98.

Bohannan, Heather. "Quest-tioning Tradition: Spiritual Transformation Images in Women's Narratives and Housekeeping, by Marilynne Robinson." Western Folklore, vol. 51, no. 1, 1992, pp. 65-79. JSTOR Arts and Science III, doi:10.2307/1499645.

Carson, Rachel Louise. Silent Spring. Hamish Hamilton, 1962.

Crisu, Corina. "At Home with Transience: Reconfiguring Female Characters of the American West in Marilynne Robinson's Housekeeping." This Life, This World: New Essays on Marilynne Robinson's Housekeeping, Gilead, and Home, edited by Jason Stevens, Brill, 2015, pp. 38-58.

Devine, Maureen. Women and Nature: Literary Reconceptualizations. Scarecrow, 1992.

Diamond, Irene, and Gloria Feman Orenstein. "Introduction." Reweaving the World: the Emergence of Ecofeminism, Sierra Club, 1999, pp. ix-xv.

Gernes, Sonia. "Transcendent Women: Uses of the Mystical in Margaret Atwood's Cat's Eye and Marilynne Robinson's Housekeeping." Religion \& Literature, vol. 23, no. 3, 1991, pp. 143-165. JSTOR Arts and Sciences V, www.jstor.org/stable/40059493.

Handley, George B. "Religion, Literature, and the Environment in the Work of Marilynne Robinson." This Life, This World: New Essays on Marilynne Robinson's Housekeeping, Gilead, and Home, edited by Jason Stevens, Brill, 2015, pp. 59-90. Kheel, Marti. "Ecofeminism and Deep Ecology: Reflections on Identity and Difference." Reweaving the World: the Emergence of Ecofeminism, edited by Irene Diamond and Gloria Feman Orenstein, Sierra Club, 1999, pp. 128-137.

Lyons, Greg. "The New West: Introduction." Literature of the American West: A Cultural Approach, Longman, 2003, pp. 419-426. 
Magagna, Tony R. "Erased by Space, Ignored by History: Place and Gender in Marilynne Robinson's West." Western American Literature, vol. 43, no. 4, 2009, pp. 345-71. Project Muse, doi:10.1353/wal.2009.0002.

Maszewska, Jadwiga. "Ecofeminist Themes in Marilynne Robinson's Housekeeping." American Studies in Scandinavia, vol. 28, 1996, pp. 63-69. www.rauli.cbs.dk/index.php/assc/article/view/1128/1131. Accessed 1 Nov. 2017. Mies, Maria, and Vandana Shiva. "Introduction." Ecofeminism, Zed Books, 2014, pp. 121.

Newman, Judie. "Solitary Sojourners in Nature: Revisionary Transcendentalism in Alison Lurie's Love and Friendship and Marilynne Robinson's Housekeeping." The Insular Dream: Obsession and Resistance, edited by Kristiaan Versluys. Free UP, 1996, pp. 303-323.

O'Brien, Sheila Ruzycki. "Housekeeping: New West Novel, Old West Film." Old West-New West: Centennial Essays, edited by Barbara Howard Meldrum, U of Idaho P, 1993, pp. 173-83.

Robinson, Forrest G. "Clio Bereft of Callope: Literature and the New Western History." The New Western History: The Territory Ahead, edited by Forrest G. Robinson, U of Arizona P, 1998, pp. 61-98.

Robinson, Marilynne. Housekeeping. Farrar Straus Giroux, 1980.

---. Mother Country. Farrar, Straus \& Giroux, 2010.

---. "Surrendering Wilderness." The Wilson Quarterly, edited by Richard Solash, 1998. archive.wilsonquarterly.com/essays/surrendering-wilderness. Accessed 1 Nov. 2017.

Vance, Linda. "Ecofeminism and the Politics of Reality." Ecofeminism: Women, Animals, Nature, edited by Greta Gaard, Temple UP, 1993, pp. 118-145.

White, Richard. "It's Your Misfortune and None of My Own": A New History of the American West, U of Oklahoma P, 1991.

Worster, Donald. "Beyond the Agrarian Myth." Under Western Skies: Nature and History in the American West, Oxford UP, 1992, pp. 3-18. 
Amanda Zastrow is is a graduate student pursuing an MA at the University of Wisconsin-Eau Claire. She is in her final year and expected to graduate in May 2018.

RETURN TO CONTENTS (LINK) 